\title{
ALEGORÍAS TELEVISIVAS DEL FRANQUISMO. NARCISO IBÁÑEZ SERRADOR Y LAS HISTORIAS PARA NO DORMIR (1966-1982)
}

\section{PAGNONI BERNS, FERNANDO GABRIEL}

\author{
Cádiz, 2019, Editorial UCA, Universidad de Cádiz, \\ Colección Faro de la Memoria, no 3, 240 páginas \\ ISBN: 978-84-9828-796-7 \\ e-ISBN 978-84-9828-797-4
}

De la joven pero prestigiosa colección "Faro de la Memoria", emanada de la Editorial de la Universidad de Cádiz y con un Consejo asesor integrado por miembros de Universidades de gran ranking, nos viene un nuevo título, el tercero tras dos soberbios volúmenes dedicados a los curas obreros en el tardofranquismo y el fascinante mundo de la masonería. Se trata de Alegorías televisivas del franquismo. Narciso Ibánez Serrador y las Historias para no dormir (1966-1982), que nos ofrece una original visión de, cómo la memoria colectiva ante una situación política e ideológica de represión, puede llegar a ser capaz de buscar vericuetos para expresar o censurar, en su caso, dicha opresión desde las herramientas más inesperadas e inusuales como son las artísticas y creativas. Su autor, Fernando Pagnoni, profesor de Literatura de la Universidad de Buenos Aires, vuelca una de sus especialidades investigadoras como es el estudio del terror como "arte combinado" en una interesante propuesta, cuya principal hipótesis de investigación, es demostrar que la obra del gran guionista y director de cine y televisión Ibáñez Serrador, lejos de un supuesto cliché de frívolo e incluso dócil con la dictadura franquista -identifica parcelas de caricaturización franquista incluso en Don Cicuta y en las tacañonas del programa-concurso “Un, Dos, Tres”-, planteó en su momento una firme y declarada crítica al régimen y a sus políticas. Y ello lo hace especialmente, desde una de las más recordadas producciones del divulgador como fueron sus "Historias para no Dormir". Una serie de obras breves, emitidas en tres temporadas -1966, 1967-1968 y 1982-, imbuidas por autores clásicos y coetáneos y en donde, la apariencia de historias de terror no solo planteaba además "historias para asustar sino para pensar", como reiteraba el propio Ibáñez Serrador en algunas de sus presentaciones. Pagnoni demuestra además cómo se insertaban situaciones, tipologías y registros escénicos que desprendían un claro discurso de denuncia a muchas de los escenarios que en la España de Franco se ignoraban o silenciaban. El imborrable recuerdo en la noche de tantos hogares 
españoles, temerosos en sus casas ante sus televisores, presenciando la inolvidable cabecera de la puerta crujiente cerrada de cuajo y el grito desgarrador, desgranó según el autor un rosario de alegorías y metáforas que, desde los diversos guiones de aparente miedo, evidenció un estructurado alegato en contra del sistema. No era solo el miedo y el terror. Algo más se encerraba en aquellas historias, realizadas con pocos medios, pero con un gran respaldo de autores -Ray Bradbury, Edgar Allan Poe-, sin olvidar la labor como guionista de Luis Peñafiel y, por supuesto, un elenco de jóvenes artistas y no tan jóvenes que cubrieron una época irrepetible del teatro y la escena desde la televisión -los hermanos Gutiérrez Caba, las hermanas Goyanes, Paco Morán, Tota Alba, Gemma Cuervo, José María Prada, José Orjas, Carlos Larrañaga o Fiorella Faltoyano entre otros-. La extemporaneidad o los argumentos de muchas de aquellas narraciones servían para camuflar palpables denuncias, como la situación de la mujer, la falta de libertad, la represión a los vencidos en la posguerra o la falta de perspectiva de muchas españolas y españoles de entonces. Pero el estudio no es un verso suelto ajeno a una composición. Pagnoni se encarga de dar sentido y coherencia a una trayectoria, la de Narciso Ibáñez Serrador, que ya bebe en Argentina, antes de su llegada a España, de las aptitudes y trabajos como guionistas, directores y experiencias escénicas en definitiva, tanto de su madre Pepita Serrador como de su padre Narciso Ibáñez Menta, que se convertirá en su infatigable escudero, también en la etapa española. Aunque en realidad, el autor apura la generación anterior, la de sus abuelos, como impronta y precedente de sus inquietudes artísticas -capítulo 2-. También pormenoriza los entresijos de su llegada a España, su ida y vuelta entre esta y su país natal y la cristalización del proyecto de las Historias, que determinaron principalmente su posterior y definitivo afincamiento en la piel de toro.

El estudio se inicia con un bloque que nos parece atinado -introducción y capítulo 1-, ya que parte del concepto de terror como elemento versátil que puede servir para identificarlo en la dimensión del colectivo nacional, el de un pueblo que, como el español, llega a vivir temerosamente el día a día de su propia vida. Realiza una pormenorizada construcción epistemológica del concepto, que usa como apoyo para construir una proposición del terroropresión del franquismo, desplegado en las principales variantes que el régimen se encargó de administrar. En este contexto describe las grandes líneas de represión social del franquismo y las conecta con un género cinematográfico de terror que, en España, resulta rudimentario y limitado.

La columna vertebral del libro se despliega en poco más de cien páginas -capítulos 3 y 4 principalmente-, donde se desarrolla el cogollo de las valoraciones que Pagnini encuentra, desglosa y disecciona en las entregas que comprendieron la serie. Un universo de treinta programas, algunos más referenciados que otros, que llenan el cuerpo del texto de valientes 
y sugerentes metáforas que correlacionan el lenguaje de los guiones con el de la realidad socioeconómica, política y cultural de la dictadura franquista. Sirva como botón de muestra algunas de las adaptaciones que Pagnini va a tomar con más referencia. En "El cumpleaños", una historia de un oficinista alienado, de vida y matrimonio monótono que termina matando a su esposa, refleja el vacío y la opresión de los españoles. Una alienación que obliga en muchos aspectos a pensar en una vida imaginaria que pueda permitir romper la dura realidad, como en "El Cohete", donde un chatarrero hace creer a sus nietos que los lleva en un cohete por el espacio. "La Espera", donde un hombre enfermo y desesperanzado aguarda que se pueda vivir en Marte, en clara alusión a otro país, a otra España no franquista. O "La sonrisa" donde se propone una distopía de una sociedad que ha olvidado reír, en clara alusión a la represión y la falta de libertad de expresión. También en "La Oferta", encuentra el autor en la figura de un mafioso condenado a muerte y pavoneado de todo lo que ha podido tener y disfrutar en la vida a costa de todos, la propia figura del general Franco. "El Asfalto", uno de los más recordados y galardonados capítulos, narra la tragedia de un viandante que queda apresado por el asfalto derretido del estío, y que termina por ser engullido ante la indiferencia de todos los que por allí pasan -una clara alusión al desentendimiento de los represaliados y su demonización, incluso a los enterrados y silenciados en fosas-. Mujeres que rompen su rol sumiso y llegan a convertirse en brujas o indeseables como en "El Tonel", o niños insumisos que rompen su corsé familiar y se erigen en monstruos como en "El Muñeco", amén de la desconfianza en lo próximo y lo ajeno - "La Alarma" y "La Pesadilla"- o de la defensa del individuo contra la masificación como en "El trasplante".

No descuida Pagnini conectar la aportación de Ibáñez Serrador con otros referentes del momento donde también expresan críticas veladas a la situación actual. Son los casos de la famosa obra de Antonio Mercero "La Cabina" o "El televisor" del propio Serrador y ya fuera del contexto de sus Historias. Una última reflexión acerca de su escasísima trayectoria en el cine con "La Residencia" y "Quien puede matar a un niño" culmina un trabajo de muy recomendable lectura, y si es posible, alternándola con el visionado de sus capítulos en la red que nos puede, como reiteraba el propio autor, ponernos a pensar y a reflexionar, como él logro al final del franquismo, "con la gente despierta durante la noche, en actitud crítica, pensando y recordando un tiempo en que aún se bebía y se reía”.

José Marchena Domínguez

Universidad de Cádiz 